Volume 15 Issue 1

DOI: http://dx.doi.org/10.53772/NMO.2021.15108

\title{
Psychotherapy from Srimad Bhagvad Geeta
}

\author{
Devendra kumar sharma \\ Corresponding author: \\ Dr. Devendra kumar sharma \\ Consultant Psychiatrist \& Ex Professor \& Head \\ Department of Psychiatry, Govt. Medical College, Kota \\ (9829085151, drdksharma1310@ rediffmail.com)
}

Ancient Indian literature is very rich in various psychotherapeutic concepts including knowledge of mind and it"s functioning like Atman, consciousness, etc. Vedas and Upanishads are the source of all Indian philosophical and psychological concepts. They have provided us the understanding of human life and methods to improve qualities of living. Srimad Bhagvad Geeta, in extract form, contains all the philosophical and psychological wisdom of Upanishads.

Geeta has described various psychiatric disorders like depression, panic, dementia, etc. For these disorders Geeta has mentioned psychotherapeutic measures. Not only this, Geeta has also mentioned a state of positive mental health and how to achieve it. Thus, Geeta should be regarded not simply a religious or holy book of Hindus but a spiritual, a psychological book whose teachings, if practiced in life, may keep every individual physically and mentally healthy. That's why the famous Indian psychiatrist Professor J S Neki has said that "In Indian context, Bhagvad Geeta is the best text book of Psychotherapy".

\section{Description of Psychopathology:}

Depression \& Panic: A very good example of description of signs and symptoms of depression and anxiety panic attack can be seen in the following verses (shlokas) when after seeing his relatives (kauravas) against whom he had to fight the battle of Kurukshetra, Arjun says:-

"सीदन्ति मम गात्राणि मुखं च परिशुष्यति।

वैपथुश्च शरीरे मे रोमहर्षश्च जायते।।(1.28)"

"गाण्डीवं स्त्रंसते हस्तात्त्वक्चैव परिदह्यते। 
न च शक्नोम्यवस्थातुं भ्रमतीव च मे मनः।।(1.29)"

"निमित्तानि च पश्यामि विपरीतानि केशव।

न च श्रेयोऽनुपश्यामि हत्वा स्वजनमाहवे।।(1.30)"

"My limbs are frozen, my mouth is drying up, my body is trembling and hairs are erecting. Gandiv, the great bow, is slipping from my hands, my skin is burning, I cannot think rationally and my mind is confused. And I see all circumstances against me. Nor do I see any good occurring upon killing my own kinsmen in the battle".

"एतात्र हन्तुमिच्छामि हनतोऽपि मधुसूदन।

अपि त्रैलोक्यराज्यस्य हेतो: किं नु महीकृते।।(1.35)"

"I don "et want to kill them even to get the kingdom of all three „Lokase then what to talk about the kingdom of earth".

Disintegration of the intellect: The comprehensive text book of Psychiatry (by Freedman \& Kaplan, III edition, Page 17) while mentioning psychological concepts in Eastern Culture of world has described a process of disintegration of intellect mentioned in Bhagvad Geeta, leading to dementia. The corresponding shlokas from Geeta are as follows:-

"ध्यायतो विषयान्पुंस: संगस्तेषूपजायते।

संगात्जायते काम: कामात्क्रोधोऽभिजायते।।(2.62)"

"क्रोधाद्भवति सम्मोह: सम्मोहात्स्मृतिविभ्रमः ।

स्मृतिभ्रंशाद् बुद्धिनाशो बुद्धिनाशात्प्रणश्यति । (2.63)"

That is, "A man thinking of object of senses becomes attached to them, attachment (आसक्ति), causes longing or craving (कामना), from longing grows anger (क्रोध), from anger arises delusion (मूढभाव), delusion leads to loss of memory (स्मृतिनाश), loss of right memory causes ruin of discriminating faculty (बुद्धिनाश), from ruins of discrimination annihilation of spiritual life (श्रेय साधन से गिरना) follows".

Psychotherapeutic measures: Geeta teaches us the science of life and art of living. It is the jewel of Indiaes spiritual wisdom spoken by Lord Shri Krishna to his close friend \& devotee Arjun. It reveals the art of taking rest by performing activities.

While performing our daily routine we often feel bordom, are tired and fatigued, which is not because of activities or actions, but because of our wrong attitude and negative mental disposition. Why do we feel stress, worries or anxiety? Geeta preaches that problem is not 
outside, but inside us, in our own attitude. We get terribly attached to, and obsessed with our body, mind or ego which causes suffering. The message of Geeta is to bring the Arjun out of depression and panic to uplift his self-esteem, to awaken him and to motivate him to perform his Sahaj Dharma of being Kshatriya i.e. duty of a warrior to destroy the evil forces (Adharma) and to re-establish the rule of law (Dharma Rajya).

Personality transformation through cognitive restructuring: Shrimad Bghagwad Geeta is an excellent example of cognitive behaviour therapy. Let us see the cognitive state of Arjun in Kurukshetra.

Situation - Warfield, where he has to kill his relatives and near dear persons.

Cognitive appraisal of the self- Means what he thinks about himself. He thinks that he is a righteous \& brave warrior and to get kingdom, killing his kith \& kin is a selfish and immoral act.

Anticipation of outcome or threat - It seems to be negative, because he thinks that even after getting kingdom he would not be happy.

Emotions \& physiological reactions expressed - Anxiety, panic, and depression.

Behaviour - Inaction i.e. He does not want to fight the war.

Psychotherapy - Krishna as cognitive psychotherapist: In first chapter Krishna only listened what Arjun wanted to say. It served as ventilation which has therapeutic value. Then in next chapter what Krishna says is for the upliftment of self-esteem of Arjun and for establishing a therapeutic alliance. Krishna corrected the cognitive distortion of Arjun by making him understand that Kauravas are representing evil and you are not going to commit any sin (pap) by killing them, rather you will earn punya by establishing a righteous kingdom (dharma Rajya).

According to Geeta cognitive restructuring leading to personality transformation of Arjun can be summarized in following 4 steps, i.e. the 18 chapters can be grouped under 4 heads: (1) Gyanyog, (2) Karmyog, (3) Bhaktiyog and (4) Dhyanyog.

- $\quad$ Gyanyog - the path of knowledge (or cognitive appraisal):

Krishna first removed the ignorance, cognitive distortions and misconceptions of Arjun \& taught him the right principle of Dharma, Krishna says -

"कुतस्त्वा कश्मलमिदं विषमे समुपस्थितम्।

अनार्यजुष्टमस्वर्ग्यमकीर्तिकरमर्जुन ।| (2.2)"

"From where this ignorance which is unheavenly and disreputable entered you at such a troublesome time O Arjun". 
"क्लैब्यं मा स्म गमः पार्थ नैतत्त्वय्युपपद्यते।

क्षुद्रं हृदयदौर्बल्यं त्यक्त्वोत्तिष्ठ परन्तप।। (2.3)"

"Do not lapse in to impotency O son of Pritha. It does not suit you. Abandon this petty feeling and weakness of the heart and rise O scorcher of enemies".

"न जायते म्रियते वा कदाचित्रायं भूत्वा भविता वा न भूयः।

अजो नित्य: शाश्वतोऽयं पुराणो न हन्यते हन्यमाने शरीरे।।(2.20)"

"This Atman is never born, nor does it die. Nor is it that this having come in to being once will never come again. This is unborn, eternal, permanent primeval. This remains unslain i.e. alive even when the body is dead".

"वासांसि जीर्णानि यथा विहाय नवानी गृहणाति नरोऽपराणि।

तथा शरीराणि विहाय जीर्णान्यन्यानि संयाति नवानि देही।।(2.22)"

"Just as a man casts off the worn out clothes and puts on new clothes, in the same way Atman casts off worn out dead bodies and goes to occupy new bodies".

"देहिनोऽस्मिन्यथा देहे कौमारं यौवनं जरा।

तथा देहान्तरप्राप्तिर्धीरस्तत्र न मुह्यति ।।(2.13)"

"In this body just like childhood, youth and old age are stages of life; similarly to get another body is also a state, so the wise people do not feel sorrow about it".

"जातस्य हि ध्रुवो मृत्युर्धुवं जन्म मृतस्य च।

तस्मादपरिहार्येऽर्थे न त्वं शोचितुमर्हसि।।(2.27)"

"Because death is certain to one that is born and rebirth is also certain to that, has died. So in this matter which is unavoidable you should not grieve".

Thus Krishna give this message to Arjun that by killing the physical body of Kauravas you are not committing a sin or an immoral act as the Atman is eternal. It cannot be killed. This concept of immortality of soul is especially soothing to a grief stricken person.

- Karmyog - Path of Action:

Krishna explains Arjun that being Kshtriya your duty (dharma) is to fight for the righteous cause which is very well narrated in this following famous verse of Geeta:- 
"कर्मण्येवाधिकारस्ते मा फलेषु कदाचन।

मा कर्मफलहेतुर्भूर्मा ते संगोऽस्त्वकर्मणि।।(2.47)"

"You should have a right to action (karma) alone and not to its fruits. Let not be the fruits of action be the motive, neither let there be any attachment to inactivity".

"सुखदु:खे समे कृत्वा लाभालाभौ जयाजयौ।

ततो युद्धाय युज्यस्व नैवं पापमवाफ्यसि।।(2.38)"

"Make grief \& happiness, loss and gain, victory and defeat, equal and then (in the serenity of this spiritual equality) ready to fight this battle. Acting in this way you won"t incur any sin".

"हतो वा प्राफ्यसि स्वर्ग जित्वा वा भोक्ष्यसे महीम्।

तस्मादुत्तिष्ठ कौन्तेय युद्धाय कृतनिश्चयः।।(2.37)"

"If you are killed in battle you will get heaven (swarga) and if you remain alive, you will enjoy kingdom on earth. Therefore get up $\mathrm{O}$ son of Kunti \& determine to fight the battle".

Krishna emphasized the importance of unattached action (Nishkam Karma). If action is performed with attachment to the result one becomes either enjoyer or sufferer, this leads to bondage (Moha). One should, therefore, derive one"s gratification from doing his duty and not from its outcome.

The principle of "nishkam karma" is appropriate for anxiety states related to action with uncertain outcome and helps a person to function effectively in this achievement oriented world.

\section{- Bhaktiyog - The path of faith:}

Faith in God (shraddha) helps an individual to dissolve his ego and to identify with the supreme soul through complete dedication \& surrender. Krishna says -

"सर्वधर्मान्परित्यज्य मामेकं शरणं व्रज।

अहं त्वा सर्वपापेभ्यो मोक्षयिष्यामि मा शुचः।।(18.66)"

"If you can"t solve your problems, then leaving all the matter, come in my shelter, I will free you from all sins \& sorrows".

Thus surrendering to God one can get rid of burden of all responsibilities \& guilt feelings. 


\section{- $\quad$ Dhyanyog - The path of peace and tranquility:}

This is the final step of personality transformation. When the darkness of ignorance is removed (gyanyoga), a man learns to do action without worrying about the outcome (nishkam karmyoga) and then dissolves his ego by surrendering to God (bhaktiyoga) he is ready to attain the supreme goal of life, i.e self-realization. This can be achieved by meditation or eight fold yoga (ashtang yoga). When one ${ }^{e e}$ mind remains unconquered its enemy within drives oneself towards lust, anger, illusion, etc. If the mind is conquered, one reaches "Param Atman" situated within himself a ,uniomystica' (aham brahmasmi) feeling which is the last stage of 8 fold yoga, i.e. ,samadhie

In Bhagwad Geeta, Krishna defines a man with positive mental health (whom he termed "stithpragya") as - A man who can act effectively in conflict-free way, he is one who is unaffected by grief, desire or has control over senses \& whose happiness comes from within. While describing stithpragya person Lord Krishna Says -

"प्रजहाति यदा कामान्सर्वान्पार्थ मनोगतान्।

आत्मन्येवात्मना तुष्टः स्थितप्रज्ञस्तदोच्यते । (2.55)"

"When a person abandons all his desires coming in his mind and when his soul is contented in itself, then he is spoken as "Stithpragya".

"दुखेष्वनुद्विग्नमनाः सुखेषु विगतस्पृहः ।

वीतरागभयक्रोधः स्थितधीर्मुनिरुच्यते । (2.56)"

"A man whose mind remains untroubled amid sorrows, who remains unattached amid pleasures and for whom longing, fear, anger have gone away, he is called the sage of firmly settled intelligence".

In this way by following and practicing the above principles mentioned in Bhagvad Geeta, and by regularly reading and living it in day to day life, one can restructure his personality and attain perfection and peace in whichever field he is working.

\section{Financial support and sponsorship}

None.

\section{Conflicts of interest}

There are no conflicts of interest. 


\section{References:}

1. Shrimad Bhagwad Geeta, Geeta Press. Gorakhpur.

2. Comprehensive Text Book of Psychiatry, Vol.1, Third Edition, Edited by H.I. Kaplan, A.M. Freedman, B.J. Sadock, Published by - Williams \& Wilkins Company, 428 E, Preston Street, Baltimore, Maryland, 21202, USA.

3. Spirituality and mental Health: Reflections of the Past: Applications in the Present; Projections for the Future. Indian Psychiatric Society 2009.

4. Shiv Gautam: Mental Health in Ancient India and its relevance to modern Psychiatry, Indian J.of Psychiatry (1999), Jan Mar, 41(1), 5-18.

5. M.S. Reddy: Psychotherapy - Insights from Bhagvad Gita, Indian J. Psychol Med. 2012, Jan Mar, 34(1), 100 - 104.

6. Subhash C Bhatia, Jaya Krishna Madabushi, Venkata Kolli, Shashi K Bhatia and Vishal Madan (2013): The Bhagvad Gita and Contemporary Psychotherapies. Indian J. Psychiatry 2013, Jan, 55 (Suppl 2), S315-S321.

7. Matcheri S. Keshvan: Building resilience in the COVID-19 era: Three paths in the Bhagvad Gita. Indian Journal of Psychiatry, Vol. 62, issue 5, Sep Oct, 2020.

How to Cite this article As: Devendra kumar sharma (2021). Psychotherapy from Srimad Bhagvad Geeta. National Medicos Organisation Journal (एन एम ओ जर्नल) (ISSN-2348-3806), 15 (1), 43-.49 Retrieved from https://nmojournal.org/index.php/nmojournal/index 